\title{
NEW WEST INDIAN BUPRESTID BEETLES
}

\author{
BY W. S. FISHER \\ Bureau of Entomology and Plant Quarantine, United States \\ Department of Agriculture
}

This paper is the result of a study of the beetles of the family Buprestidæ from the West Indies, sent to me for identification from the Museum of Comparative Zoölogy, Cambridge, Mass., by Dr. P. J. Darlington, Jr. All the new species described in this paper were collected by Dr. Darlington on his numerous trips to these islands.

\section{Paratyndaris antillarum, new species}

Short, robust, subcylindrical, rather strongly shining; body above and beneath piceous, with distinct purplish and greenish reflections in different lights.

Head feebly, uniformly convex, without a median depression; surface rather densely, coarsely, uniformly punctate, with a few very short, inconspicuous hairs, the intervals smooth; clypeus broadly, rather deeply, arcuately emarginate in front; antennæ missing.

Pronotum strongly, uniformly convex, one-third wider than long, distinctly narrower at apex than at base, widest at middle; sides strongly arcuately rounded; lateral margin, when viewed from the side, entire, and slightly arcuate; anterior margin truncate; base vaguely, transversely sinuate; disk without depressions or smooth lines; surface finely, transversely striolate, and asperate at middle, coarsely, rather densely punctate, and more or less rugose toward the sides, sparsely clothed with short, inconspicuous hairs. Scutellum glabrous, elongate-triangular.

Elytra as wide as pronotum at base; sides nearly parallel from humeral angles to behind middle (feebly constricted along basal fourth), then arcuately converging to the tips, which are separately broadly rounded, with a distinctly ele- 
vated, sinuate, preapical carina; lateral margins coarsely, irregularly serrate; disk uneven, and each elytron with a transverse depression along base, an oblique depression in front of middle, and a feeble, median gibbosity at apical third; surface irregularly striate, coarsely, irregularly punctate, more densely basally, and sparsely, irregularly clothed with moderately long, recumbent, whitish hairs.

Abdomen beneath coarsely, rather sparsely, uniformly punctate, sparsely clothed with very short, inconspicuous hairs; second sternite with the posterior margin truncate, without a distinct plate extending over the third sternite; last visible sternite terminating in an acute spine.

Length $7 \mathrm{~mm}$., width $3 \mathrm{~mm}$.

Type locality.- South side of Lake Enriquillo, Dominican Republic.

Type.-In the Museum of Comparative Zoölogy, Cambridge, Mass. Type no. 23,696. Paratype in the United States National Museum.

Described from two specimens (one type) found dead at the type locality during September 1938 by P. J. Darlington, Jr.

The type is probably a female but has not been dissected. Both specimens are more or less broken and the head is missing from the paratype. The paratype has a very small plate at posterior margin of second sternite.

This is the first species of Paratyndaris to be recorded from the West Indies. It resembles P. acaciæ Knull, but differs from that species in being shorter and more robust, in having the elytra uneven, uniform in color, and the lateral margin without two distinct teeth near apex, the second sternite without or with only a feebly indicated plate at the posterior margin, and in not having the pronotum sulcate at the middle.

\section{Buprestis hispaniolæ new species}

Female.- Broadly elongate, moderately convex above, strongly shining; pronotum brownish cupreous, with a more or less distinct greenish reflection, and ornamented with reddish yellow as follows: A rather broad vitta on each side along lateral margin extending from apical angle to near 
posterior angle, a narrow fascia on each side on anterior margin, three round spots along base, and a rounded spot at middle near anterior margin; elytra purplish brown, each elytron with two broad, irregular, reddish-yellow vittæ, the lateral one extending from humeral angle to near apex, and the sutural one from near base to apical fifth; body beneath brownish cupreous, with the prosternum, median parts of metasternum and mesosternum, femora in part, and transverse fasciæ on the sternites, reddish yellow.

Head nearly flat, purplish brown, with a transverse yellow spot on each side at vertex and several irregular yellow spots behind the clypeus, and with a short carina on the front; surface coarsely, irregularly, confluently punctate, sparsely clothed with short, erect, inconspicuous hairs; eyes feebly converging above; clypeus broadly, arcuately emarginate in front.

Pronotum twice as wide as Iong, distinctly narrower at apex than at base, widest near base; sides sinuate and strongly, obliquely diverging from apical angles to near posterior angles, which are broadly rounded; anterior margin broadly, arcuately emarginate, with the median lobe broadly, feebly rounded; base transversely sinuate; surface slightly uneven, coarsely, deeply, irregularly punctate, with a few short, inconspicuous hairs at posterior angles, the intervals smooth. Scutellum quadrate, truncate in front, broadly rounded behind.

Elytra slightly wider than base of pronotum; sides feebly expanded behind the humeri, feebly converging to apical third, then strongly, arcuately converging to the tips, which are separately transversely truncate, with a small tooth at each angle; surface striato-punctate, the striæ not deeply impressed, the punctures fine and closely placed in the striæ; intervals feebly convex, coarsely, irregularly punctate, and the intervals toward the sides more or less rugose.

Abdomen beneath coarsely, irregularly punctate, sparsely clothed with short, semierect, white hairs, the intervals obsoletely granulose; first sternite longitudinally flattened at middle; last visible sternite sinuately rounded at apex. Prosternum coarsely, sparsely punctate, sparsely clothed with short, recumbent, whitish hairs; prosternal process 
flattened at middle, obliquely expanded from anterior coxal cavities to the apex, which is acute.

Length $18-20 \mathrm{~mm}$., width 7-7.5 $\mathrm{mm}$.

Male.-Unknown.

Type locality.- Between Constanza and Jarabacoa, at an altitude of 2,000 to 4,000 feet, Dominican Republic.

Type.- In the Museum of Comparative Zoölogy, Cambridge, Mass. Type no. 23,697. Paratype in the United States National Museum.

Described from two females (one type) both collected by P. J. Darlington, Jr. The type was collected at the type locality during August 1938, and the paratype was collected in the foothills of the Cordillera Central, south of Santiago, Dominican Republic, during June 1938.

This species resembles Buprestis lineata F., but it differs from that species in having the pronotum and underside of body ornamented with reddish-yellow spots. The reddishyellow spots on the underside of the body in the two specimens examined are more or less variable in shape.

Peronæmis insulicola, new species

Male.-Rather narrowly agriliform, rounded in front, more acuminate behind, glabrous, rather strongly shining; head bluish green in front, becoming violaceous on occiput; pronotum dark green, with a more or less distinct violaceous tinge on certain parts; elytra dark violaceous green, bronzy green along sutural margins; body beneath green, with a golden reflection on abdomen, more strongly shining than above, and the legs in part bluish green.

Head nearly flat in front, with a vague, longitudinal carina on occiput; surface coarsely, deeply, densely, uniformly punctate, the intervals finely granulose; clypeus wide between the antennal cavities, feebly, transversely concave, broadly, shallowly, angularly emarginate in front.

Pronotum rather strongly convex, strongly deflexed at sides, one-third wider than long, slightly wider at base than at apex, widest at middle; sides feebly, arcuately rounded; anterior margin feebly sinuate, with a feeble, broadly rounded, median lobe; base nearly transversely truncate; lateral margin when viewed from the side sharply defined, 
arcuate, extending from base to near apical angle; disk with three large, deep, basal depressions, the median one not extending to middle, with a deep fovea in front of scutellum, the lateral ones extending to middle of pronotum; surface coarsely, deeply, densely, uniformly punctate, the intervals finely, densely granulose. Scutellum twice as wide as long; sides feebly rounded; surface nearly smooth.

Elytra as wide as pronotum at base; sides broadly, angularly expanded behind humeral angles, nearly parallel to middle, then strongly, obliquely converging to the tips, which are acute; lateral margins coarsely, irregularly serrate; basal depressions rather deep and broadly transverse; surace irregularly striato-punctate, more or less rugose basally, the intervals finely, densely granulose, with a few coarse punctures intermixed.

Body beneath coarsely, rather densely, irregularly punctate, finely granulose, sparsely clothed with moderately long, erect, inconspicuous hairs; last visible sternite feebly, arcuately emarginate at apex.

Length $10 \mathrm{~mm}$., width $3.25 \mathrm{~mm}$.

Female.-Unknown.

Type locality.-Between Constanza and Jarabacoa, at an altitude of 2,000 to 4,000 feet, Dominican Republic.

Type.- In the Museum of Comparative Zoölogy, Cambridge, Mass. Type no. 23,698.

Described from a unique male collected at the type locality during August 1938 by P. J. Darlington, Jr.

This species is allied to Peronxmis monticola Fisher, but it differs from that species in being of a more uniform color above, in having the pronotum rounded at the sides, the elytra strongly angulated behind the humeral angles, and in not having a finely punctured vitta along the sutural margins of the elytra.

\section{Enbrachys gibbipennis, new species}

Male.-Ovate, nearly twice as long as wide, broadly rounded in front, more attenuate posteriorly, strongly shining, glabrous ; head and pronotum green, more or less bronzy; the latter with the elevated median part piceous; elytra uniformly piceous; body beneath piceous, with an indistinct purplish tinge. 
Head moderately convex, broadly, longitudinally depressed in front, with a narrow, longitudinal groove extending from clypeus to middle of front, deeply, narrowly, transversely depressed behind clypeus, with three deep foveæ in the depression, one median and two lateral; surface densely, coarsely granulose, with numerous coarse, shallow punctures intermixed; antennal cavities nearly contiguous in front.

Pronotum nearly three times as wide as long at middle, considerably narrower at apex than at base, widest near base; sides parallel along basal third, then strongly, obliquely converging to the apical angles, which are acute; posterior angles subrectangular; when viewed from the side the lateral margin is straight anteriorly, arcuate near posterior angle for the reception of the anterior leg; anterior margin deeply, broadly, arcuately emarginate; base transversely sinuate on each side, the median lobe strongly produced, and broadly truncate in front of scutellum, disk with the anteromedian part strongly, transversely convex, narrowly flattened along base, and very broadly flattened and uneven at the sides; surface coarsely, sparsely punctate on convex median part, densely granulose, with a few coarse punctures intermixed on the flattened areas. Scutellum triangular, distinctly wider than long.

Elytra nearly as wide as pronotum at base; humeral angles broadly rounded; sides parallel from humeral angles to middle, then obliquely converging to the tips, which are conjointly broadly rounded; lateral margins feebly serrate; surface very uneven, coarsely, sparsely, shallowly, irregularly punctate, and each elytron with moderately elevated, broadly rounded gibbosities as follows: An oblique one on humerus, an elongate one along sutural margin behind scutellum, a rounded one near lateral margin just behind the middle, and an elongate one near apex.

Abdomen beneath vaguely granulose or reticulate, with a few shallow, inconspicuous punctures intermixed; last visible sternite broadly rounded at apex, the apical groove deep, and following outline of lateral margins. Prosternum feebly reticulate, sparsely, coarsely, shallowly punctate; prosternal process broad, the sides obliquely converging to the apex, which is broadly rounded. 
Female. - Differs from the male in being uniformly piceous, with a more or less distinct cupreous reflection, and in having the last visible sternite more broadly subtruncate at apex.

Length $2.75 \mathrm{~mm}$., width $1.5 \mathrm{~mm}$.

Type locality.- Mt. Diego de Ocampo, at an altitude of 3,000 to 4,000 feet, Dominican Republic.

Type and allotype.- In the Museum of Comparative Zoölogy, Cambridge, Mass. Type no. 23,699. Paratypes in the United States National Museum.

Described from four specimens, two males and two females (one male type), all collected at the type locality during July 1938 by P. J. Darlington, Jr.

This species resembles Enbrachys otero Fisher, from which it differs in having the front of the head more shallowly depressed, the sides of the pronotum more strongly flattened, and in not having the gibbosities on the elytra so abruptly elevated.

\section{Leiopleura darlingtoni, new species}

Oblong, rather strongly convex above, broadly rounded in front, more strongly narrowed posteriorly; head yellowish cupreous; pronotum reddish cupreous on convex median part, bronzy green on flattened area at sides; scutellum bright blue; elytra opaque olivaceous green, with a quadrate, opaque, blue spot behind the scutellum, a large, shining, piceous area on each side along lateral margin behind humerus, and a similar area in front of scutellum, common to both elytra; body beneath black, with a faint purplish reflection, and strongly shining.

Head strongly, uniformly convex, with four deep, round foveæ behind the clypeus; surface densely, coarsely reticulate, with a few shallow, indistinct punctures intermixed; antennæ uniformly piceous, nearly contiguous at bases.

Pronotum twice as wide as long, distinctly narrower at apex than at base, widest along basal half, strongly, uniformly convex on antero-median part, strongly flattened along base and on each side along lateral margin; sides strongly, arcuately diverging from apical angles to middle, then parallel to the posterior angles; anterior margin subtruncate; base transversely sinuate on each side, the median 
lobe feebly produced and broadly truncate in front of scutellum, surface coarsely, densely reticulate, with a few shallow, inconspicuous punctures intermixed. Scutellum triangular, nearly twice as wide as long, densely granulose, the granules flattened on top, resembling round, microscopic scales.

Elytra slightly wider than base of pronotum, rather strongly convex, broadly depressed along lateral margins behind humeri; humeral angles obtusely rounded; sides parallel and feebly sinuate from humeral angles to middle, then arcuately converging to the tips, which are conjointly broadly rounded, the lateral margins not distinctly serrate; humeri strongly elevated; surface densely granulose and sparsely, coarsely punctate on the olivaceous-green and bright-blue areas, the granules similar to those on the scutellum, and sparsely, coarsely punctate on the shining piceous areas.

Abdomen beneath densely, obsoletely reticulate, with a few inconspicuous punctures intermixed; last visible sternite broadly rounded at apex. Prosternum obsoletely reticulate, with a few coarse punctures intermixed, the groove for the insertion of the antenna short and shallow. Metasternum shallowly emarginate in front.

Length $2 \mathrm{~mm}$., width $0.8 \mathrm{~mm}$.

Type locality._- Labeled "R. Froide, Port-au-Prince, Haiti."

Type.- In the Museum of Comparative Zoölogy, Cambridge, Mass. Type no. 23,700.

Described from a single specimen collected at the type locality October 3,1934 , by P. J. Darlington, Jr., to whom I take great pleasure in dedicating the species.

This species differs from all the known species of Leiopleura in having the peculiar scale-like sculpture on the elytra and scutellum.

Micrasta puertoricensis, new species

Male.- Oblong oval, equally rounded in front and behind, moderately shining, glabrous; uniformly black, with an indistinct bronzy tinge above; body beneath black, with a faint purplish reflection, the tarsi yellowish, with the tarsal lamellæ whitish.

Head feebly convex, when viewed from above forming a 
regular arc with the pronotum; surface densely alutaceous, sparsely, coarsely, shallowly punctate; front with the sides parallel; clypeus not transversely depressed, feebly constricted between the antennal cavities, feebly, broadly emarginate in front. Antenna extending beyond base of pronotum, sparsely clothed with long, erect, whitish hairs; first and second segments globuse, subequal in length; third distinctly narrower, feebly expanded at middle, subequal in length to the second; the following segments rather robust, subequal in length, slightly triangular, the last segment longer than the tenth, and acute at apex.

Pronotum strongly, uniformly convex, feebly, transversely flattened along base, twice as wide as long, distinctly narrower at apex than at base, widest behind middle; sides strongly, arcuately converging anteriorly, slightly converging near posterior angles; when viewed from the side the marginal and submarginal carinæ feebly arcuate, widely separated for nearly their entire length, and united at base, the marginal carina more or less obsolete anteriorly; anterior margin feebly, arcuately emarginate; base transversely truncate; surface feebly alutaceous, sparsely, coarsely, shallowly punctate. Scutellum triangular, acute at apex.

Elytra as wide as pronotum at base; sides parallel from humeral angles to apical third, then arcuately converging to the tips, which are conjointly broadly rounded; humeri not prominent; disk uniformly convex, with a shallow, transverse depression at base of each elytron; surface feebly, sparsely punctate, the intervals nearly smooth.

Abdomen beneath feebly convex, feebly reticulate, vaguely punctate, clothed with a few short, erect, inconspicuous hairs; basal sternite with a round, median depression, which is densely clothed with long, erect hairs; last visible sternite broadly rounded at apex. Prosternum moderately convex, coarsely, sparsely punctate; anterior margin subtruncate; prosternal process broad, the sides parallel, and broadly truncate at apex. Femora moderately robust. Tibiæ straight and slender.

Length $1.25 \mathrm{~mm}$., width $0.6 \mathrm{~mm}$.

Type locality.- Maricao Forest, at an altitude of 2,000 to 3,000 feet, Puerto Rico. 
Type.- In the Museum of Comparative Zoölogy, Cambridge, Mass. Type no. 23,701. Paratype in the United States National Museum.

Described from two males (one type) collected at the type locality between May 30 and June 2, 1938, by P. J. Darlington, Jr.

This species resembles Micrasta oakleyi Fisher, but differs from that species in being uniformly black with an indistinct bronzy-green tinge, in having the marginal carina on the pronotum more or less obsolete anteriorly, the pronotum feebly, transversely depressed along the base, the scutellum acute at the apex, the surface of the elytra more feebly punctured, and in not having the clypeus transversely depressed.

Micrasta subcylindrica, new species

Female.- Differs from Micrasta puertoricensis Fisher as follows: Elongate, subcylindrical, and strongly convex above, strongly shining, piceous; pronotum more coarsely punctured, widest at middle, with the sides arcuately rounded; head coarsely, sparsely punctate, feebly, longitudinally depressed at middle; scutellum longer than wide, acute at apex; each elytron with a broad, triangular depression at base; abdomen and prosternum coarsely, densely punctate, the basal sternite without a round, median depression clothed with long hairs (this is a male sexual character); and the tarsi and apical halves of tibiæ yellowish.

Length $2 \mathrm{~mm}$., width $0.75 \mathrm{~mm}$.

Type locality.- Soledad (Cienfuegos), Cuba.

Type.- In the Museum of Comparative Zoölogy, Cambridge, Mass. Type no. 23,702.

Described from a unique female collected during May 1936 by P. J. Darlington, Jr.

\section{Micrasta monticola, new species}

Male.-Differs from Micrasta puertoricensis Fisher in being more robust, more strongly convex above, strongly shining, uniformly bronzy brown, and in having the pronotum and elytra coarsely, rather densely punctate, with the intervals smooth, pronotum widest along basal half, with the sides nearly parallel posteriorly, scutellum longer than 
wide, and acute at apex, elytra with the sides parallel from humeral angles to middle, and each elytron with a distinct, rather broad, transverse groove at base, the last visible sternite broadly rounded at apex, and in having the intermediate sternites narrowly, transversely grooved at the middle.

Length $2 \mathrm{~mm}$., width $1 \mathrm{~mm}$.

Type locality. - Mt. Diego de Ocampo, at an altitude of 3,000 to 4,000 feet, Dominican Republic.

Type.- In the Museum of Comparative Zoölogy, Cambridge, Mass. Type no. 23,703.

Described from a unique male collected during July 1938 by P. J. Darlington, Jr.

\section{Micrasta hispaniolæ, new species}

Female.- Differs from Micrasta monticola Fisher in being uniformly bluish black, subopaque, in having the pronotum widest at the middle, with the sides arcuately converging posteriorly, and the surface rather densely, coarsely punctate, with the intervals distinctly alutaceous, and in having the sides of the elytra parallel from humeral angles to apical third. It also resembles Micrasta puertoricensis Fisher, but it differs from that species in being more robust, more strongly convex above, subopaque, in having the pronotum and elytra rather densely, coarsely punctate, with the intervals distinctly alutaceous, and in having a distinct, broad, transverse depression at the base of each elytron.

Length $2 \mathrm{~mm}$., width $1 \mathrm{~mm}$.

Type locality. - Foothills of the Cordillera Central, south of Santiago, Dominican Republic.

Type.- In the Museum of Comparative Zoölogy, Cambridge, Mass. Type no. 23,704.

Described from a unique female collected during June 1938 by P. J. Darlington, Jr.

It is just possible that this may be the female of monticola Fisher, but on account of the differences given and without additional notes on their habits it seems advisable to consider them to be two distinct species. There does not seem to be a good series of any of the described species of this genus available for study, so it is impossible to decide what variation occurs in the species. 

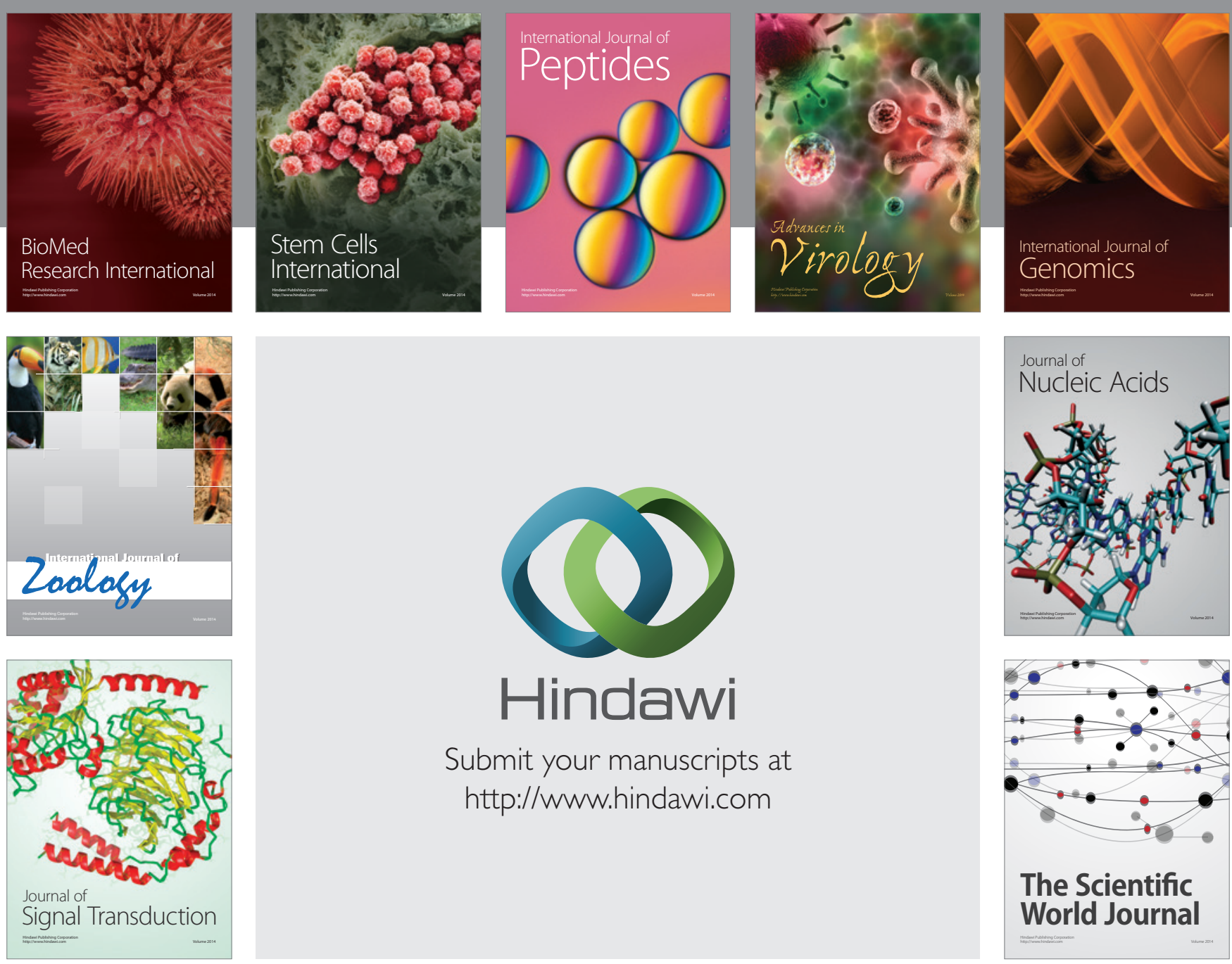

Submit your manuscripts at

http://www.hindawi.com
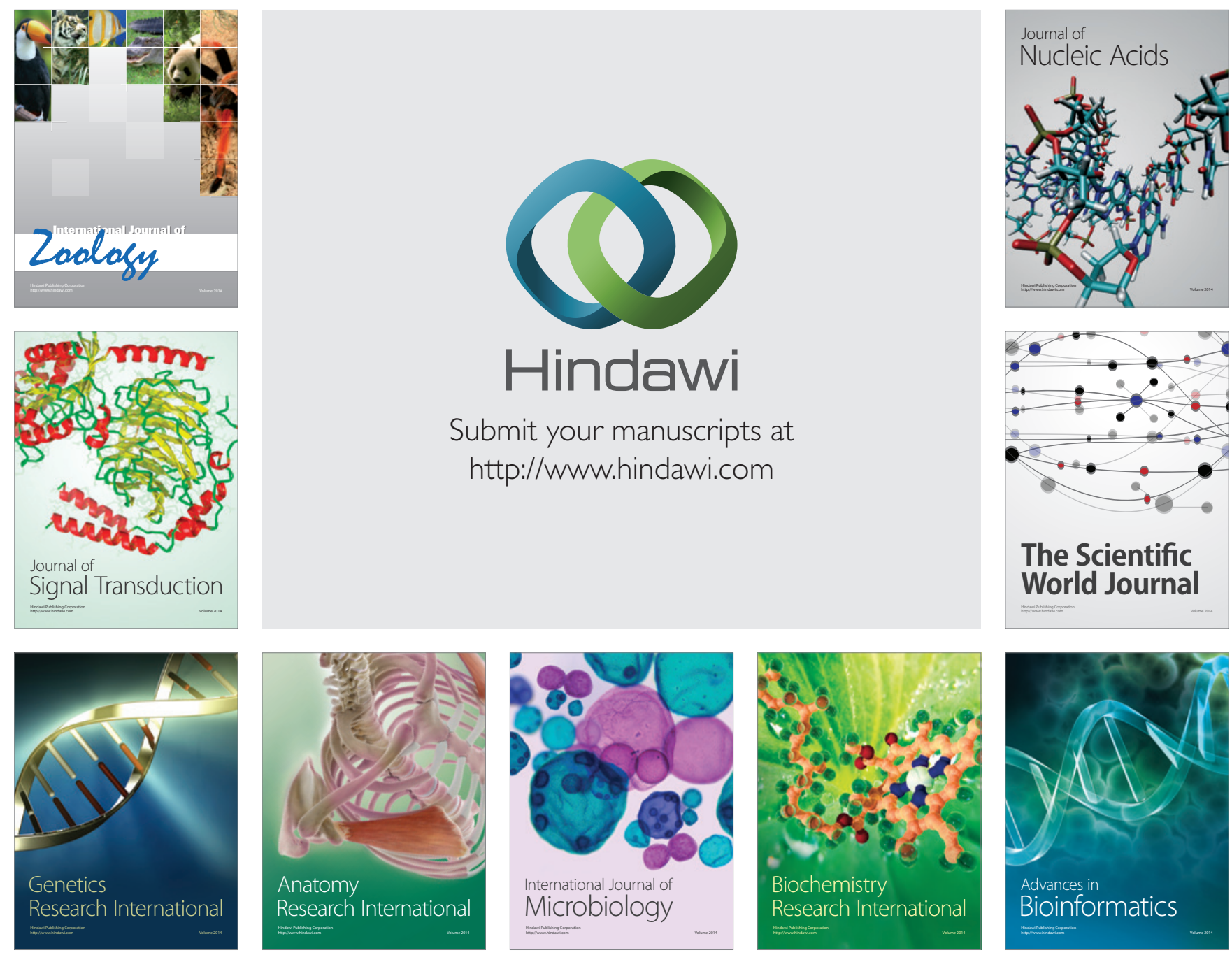

The Scientific World Journal
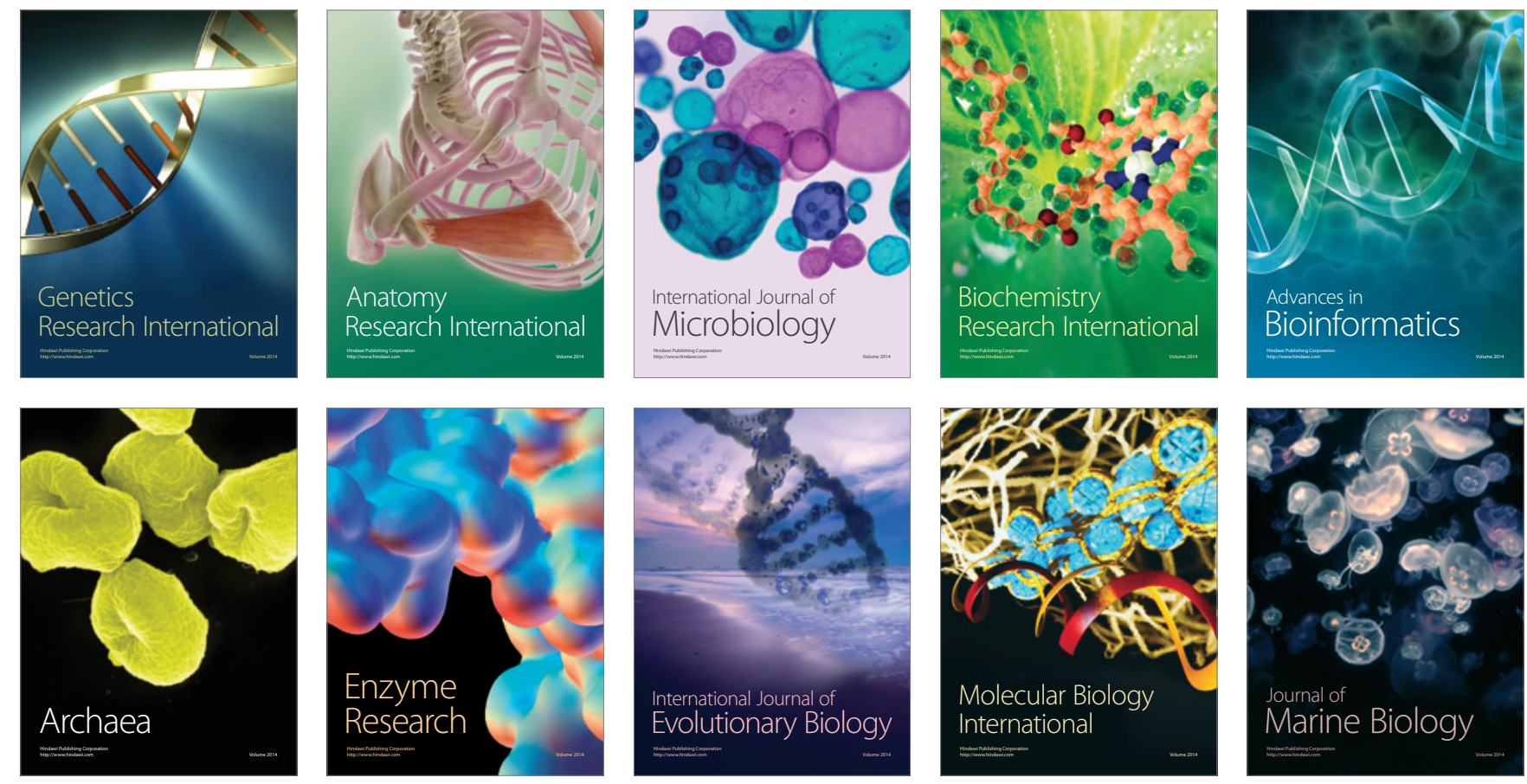